\title{
Prevalence and associated factors of treatment failure among HIV/AIDS patients on HAART attending University of Gondar Referral Hospital Northwest Ethiopia
}

\author{
Gizachew Ayele ${ }^{1 *}\left(\mathbb{D}\right.$, Belay Tessema², Anteneh Amsalu², Getachew Ferede ${ }^{2}$ and Gizachew Yismaw ${ }^{2}$
}

\begin{abstract}
Background: The initiation of highly active antiretroviral therapy (HAART) plays a significant role in the clinical management of HIV infected people by preventing morbidity and mortality. This benefit becomes, the most terrible when treatment failure develops. Thus, this research aims to assess the prevalence and associated factors of treatment failure among HIV/AIDS patients on HAART attending University of Gondar Referral Hospital Northwest Ethiopia.

Results: Patients on ART with a minimum of 6 months and up to 12 years of treatment were being enrolled. The prevalence of treatment failure, immunological failure and virological failure among people living with HIV/AIDS attending University of Gondar referral hospital were 20.3, 13.2, and 14.7\%, respectively. Patients who had no formal education (Adjusted odds ratio (AOR): 3.8; 95\% Cl, 1.05-13.77), primary level education (AOR: 4.2; 95\% Cl, 1.16-15.01) and duration on ART < 6 years (AOR: 2.1; 95\%Cl, 1.12-3.81) were a significant risk factor. However, initial adult regimen D4T + 3TC+ EFV (AOR: $0.025 ; 95 \%$ Cl, 0.002-0.36), AZT +3TC + NVP (AOR: $0.07 ; 95 \% \mathrm{Cl}, 0.01-0.71$ ), AZT + 3TC + EFV (AOR: $0.046 ; 95 \% \mathrm{Cl}, 0.004-0.57$ ) andTDF+3TC + EFV (AOR: 0.04; 95\% Cl, 0.004-0.46) were significantly protective for treatment failure.

Conclusions: Timely and early identification of associated factors and monitoring antiretroviral therapy treatment failure should be done to enhance the benefit and to prevent further complication of the patients. It is preferable to initiate ART using any one of the following ART regimens: AZT +3TC + NVP, AZT + 3TC + EFV and TDF + 3TC + EFV to prevent treatment failure. Since the prevalence of this treatment failure and its associated factor may be different from other ART centers and community in Ethiopia, further national representative institutional based cross-sectional researches are needed across all ART centers of Ethiopia in order to determine the prevalence of treatment failure and its associated factors.
\end{abstract}

Keywords: HIV/AIDs, Treatment failure, Immunological failure, Virological failure

\section{Background}

Human immunodeficiency virus (HIV) has affected all parts of the world. According to the 2017 UNAIDS report, 36.7 million people were living with HIV in the world. In the same year, one million people died from acquired immunodeficiency syndrome (AIDS) related illnesses and 1.8 million were new HIV infected people

\footnotetext{
* Correspondence: ayele.gizachew@yahoo.com

${ }^{1}$ College of Health Sciences, Mizan-Tepi University, P.O. BoX 206, Mizan Teferi, Ethiopia

Full list of author information is available at the end of the article
}

[1]. Sub-Saharan Africa is a region highly affected by HIV epidemic. Ethiopia is one of the Sub-Saharan African countries with the highest numbers of people affected by the problem $[2,3]$. In Ethiopia, there were 710,000 patients infected with HIV/AIDS in 2016. Around 404,405 HIV patients were on an Antiretroviral therapy (ART) and around 20,000 AIDS-related deaths were reported in the same year [1]. In Amhara regional state, where this research carried out, 191,067 people were living with HIV/AIDS in 2015 [4].

(c) The Author(s). 2018 Open Access This article is distributed under the terms of the Creative Commons Attribution 4.0 International License (http://creativecommons.org/licenses/by/4.0/), which permits unrestricted use, distribution, and reproduction in any medium, provided you give appropriate credit to the original author(s) and the source, provide a link to the Creative Commons license, and indicate if changes were made. The Creative Commons Public Domain Dedication waiver (http://creativecommons.org/publicdomain/zero/1.0/) applies to the data made available in this article, unless otherwise stated. 
Even though, lack of remedial therapy for HIV/AIDS, the initiation of ART played an important role in the clinical management of peoples infected with of HIV/ AIDS [5]. But a significant number of patients fail to achieve a sustained virological and immunological response to treatment among the HIV-infected patients receiving highly active antiretroviral therapy (HAART) [6].

Antiretroviral (ARV) treatment failure is defined as progression of disease and high risk of mortality after beginning of HAART. It can be assessed by clinical failure (occurrence of new infections (OI) or malignancy, symptomatic of clinical disease progression; recurrence of previous OI, onset, or recurrence of WHO stage IV (\& certain stage III) conditions, etc.), immunologic failure (a decline in the CD4+ T cell count), or virological failure (The inability to maintain suppression of viral replication to an HIV RNA level < 1000) either in combination or discordantly. Clinical and immunologic criteria have been used for assessing treatment failure in the absence of viral load (VL) test [7-10]. If VL test is available, VL determination and guiding of ART treatment by the gold standard test (VL test) should be recommended [11]. The discordant immune response in patients those doesn't show a significant increase in the CD4+ $T$ cell count despite viral suppression may also asses with VL and immunological criteria [12, 13].

The patients who had failed ARV therapy treatment are attributed to the higher number of side effects and have the greatest likelihood of experiencing drug resistance and treatment fatigue as a result of being on treatment longer [14]. Development of drug-resistant virus strains (restricting ART alternatives) can be an additional threat if this virus begins to transmit in the population $[15,16]$. Therefore, early detection of treatment failure is crucial to sustaining the success of the treatment [17, 18]. Studies conducted in East Africa have revealed that a high prevalence of immunologic failure ranging from 11 to $57 \%$ among clients on HAART; moreover, the extent increases as the time of follow-up increases [1921]. The immunological failure rate in Ethiopia was also found to be high [22].

The timing and accuracy of identifying the risk factors associated with treatment failure include socio-demog raphic factors (e.g., sex, marital status, educational level, etc.) and clinical factors (e.g., adherence, WHO stage, drug toxicity, ART regimen, CD4+ T cell count, etc.) [23-25] helps to describe timely predictors of treatment efficacy that permit better use of drugs, to avoid unnecessary side effects of ART drug and prevent drug resistance new strain viruses. Identification of risk factors also decrease the economic weight due to a magnificence cost of ART drug and will help as a guide for health professionals and higher officials to alleviate the problem and to develop strategies toward the decreasing rate of treatment failure.
In Ethiopia, viral load determination and guiding ART treatment with the gold standard test (viral load) has started recently because of resource limitation. Consequently, there is limited data on treatment failure and its associated risk factor. The available studies [26, 27] were conducted on first-line antiretroviral treatment failure. These studies didn't address second-line and immunovirological discordance of treatment failure.

Ethiopia started to implement an ambitious plan launched by UNAIDS in 2014 known as "90-90-90". This will focus to achieve, at least $73 \%$ of all HIV patients will be virally suppressed in 2020 and to end the AIDS epidemic by 2030 . The $90-90-90$ ambition plan intends to, by 2020 ; $90 \%$ infected individuals with HIV will be diagnosed, 90\% diagnosed patients will be receiving ART drug and the viral load in $90 \%$ of patients on ART will be undetectable [28]. To achieve this goal, data on immunological and virological treatment failure is required.

Furthermore, the Ethiopia national treatment program needs data to aid the realizing high impact and targeted prevention program; to achive successful elimination of mother to child transmission and improving sustainable quality care and management. Thus, this research was carried out to offer data on prevalence and associated factors of treatment failure among HIV/AIDS patients on HAART attending University of Gondar Referral Hospital Northwest Ethiopia.

\section{Materials and method}

\section{Study area, design, period and population}

A hospital based cross-sectional study and retrospective record review was conducted from February to April 2017. The study was conducted at University of Gondar Referral Hospital which is found at Gondar town, the town is located $747 \mathrm{~km}$ from the capital city of the country, Addis Ababa and $182 \mathrm{~km}$ far from Bahir Dar which is the capital city of Amhara regional state. According to the recent administration, the town has 12 sub cities which consist of 21 kebeles. Gondar is one of the ancient and densely populated towns in Ethiopia. Based on the figure from the central statistical agency in 2008, Gondar has an estimated population of more than 206,987 (98,085 males and 108,902 females) [29]. In Gondar town, there is one teaching referral hospital providing specialized clinical services, 8 health centers, and 15 private clinics serving the population. Currently 13,753 HIV patients and 5389 on ART patients are attending at the University of Gondar Referral Hospital.

All people living with HIV/AIDS (PLWHIV) and those enrolled in UOG Referral Hospital ART laboratory was the source population. Adult HIV patients who had received ART for more than 6 months, who visit UOG referral hospital ART laboratory during the study period and who consented to be involved in the study was the study population. 
All adult people living with HIV and those had had base line CD4 + T cell count, at least 6 months follow up duration of ART and those patients willing to give blood for $\mathrm{VL}$ and CD4+ T cell count were included in the study.

Patients who had been seriously sick, unable to give information, incomplete data specially laboratory and clinical data such as:- base line CD4+ T count, base line adherence, base line drug regimen, HIV/AIDS WHO stage, weight, etc., insufficient sample and who were less than 18 years during the study period were excluded from study.

\section{Operational definition of terms \\ Base line data}

The data before ART initiation.

\section{Immunological failure}

Fall of follow-up CD4 count to baseline (or CD4 falls below baseline), or CD4 levels persisting below 100 cells $/ \mathrm{mm} 3$, or $50 \%$ fall from on-treatment peak value.

\section{Virological failure}

Plasma viral load greater than 1000 copies/ ml.

\section{Responders}

Which is sub divided as immunological non-responders (VL $>150$ copies $/ \mathrm{ml}$ and $\mathrm{CD} 4+$ cells increase $\geq 50 / \mu \mathrm{l}$ ) or (VL $<150$ copies $/ \mathrm{ml}$ and $\mathrm{CD} 4+$ cells increase $<50$ cells $/ \mu \mathrm{l}$ ), in comparison with baseline values.

\section{Adherence}

$$
\frac{\text { No of dose of HAART taken }}{\text { No of prescribed doses of HAART }} \times 100 \%
$$

Good adherence, $>95 \%$, fair adherence, $85-95 \%$ and poor adherence, $<85 \%$ doses take $[30,31]$.

\section{Sample size determination and sampling technique}

Based on single population formula and systematic random sampling technique with the following assumption, $\mathrm{P}=$ population proportion (estimated prevalence) $=0.5$, precision, 0.05 , by assuming 95\% confidence interval $\alpha=$ 0.05 and $z(1-\mathrm{a} / 2)=1.96 \mathrm{~d}$ was used for sample size determination. Tree hundred eghity four $(n=384)$ was the minimum sample size. By adding up 10\% non-response rate 423 participants were involved.

The average number of HIV/AIDS patients per day under follow up who had given blood for VL and CD4+ $\mathrm{T}$ cell count concurrently was 20 . During the 3-month data, collection time 1320 HIV/AIDS patients on HAART ( $>6$ month) were expected to visit the hospital for VL and CD4+ T cell count follow up. Sampling interval (K value) was calculated with $1320 / 423=3.12=3$.
Thus interviews, chart review and blood collection for $\mathrm{VL}$ and $\mathrm{CD} 4+\mathrm{T}$ cell count were conducted at 3 intervals. To determine the first person lottery method was used for the number of patients who had given blood for $\mathrm{VL}$ and CD4+ T cell count concurrently at 1st day from the 20 patients. Then each 3rd client was selected for interview, for their chart review and for VL and CD4+ T cell count. If the 3rd patient was absent, clients with their chart were excluded because of incomplete data and seriously sick clients those were excluded because of incapable to give information; the next person was taken as a study subject. The sampling procedure is simplified in the Fig. 1.

\section{Data collection}

\section{Socio-demographic data}

Socio-demography and potential risk factors data not documented on chart (Alcohol intake, chewing khat, cigarette smoking, etc.) were collected with interview from each study participant using structured questionnaires and relevant clinical features (weight, WHO clinical stage, base line $\mathrm{CD} 4+\mathrm{T}$ cell count and other consecutive $\mathrm{CD} 4+\mathrm{T}$ cell count after ART initiation, ART regimen, adherence and duration of HAART, initial regimen, types of co- infections, adverse effect, reason of switching drug) of the patients were retrieved from charts (medical records) by trained nurses working on ART clinic using data extraction checklist. Blood for both CD4 and viral load tests were collected by the laboratory staff at sample collection site.

\section{Sample collection and transport}

Following standard operational procedure (SOP) sample collection and transport was done. About $10 \mathrm{ml}$ venous blood was collected from each patient for CD4 and Viral load tests on the same venipuncture. For both tests $3-5$ $\mathrm{ml}$ of whole blood was drawn from each participant using vacutainer tube separately in two tube containing anticoagulant ethylene diamine tetra-acetic acid (EDTA). After centrifugation (3000 rpm for $20 \mathrm{~min}$ ) plasma was separated and aliquots prepared for viral load testing. Specimens collected were labeled with ART number, study IDs and date and transported directly to the laboratory for $\mathrm{CD} 4+\mathrm{T}$ cell count and to the molecular laboratory for VL test. The storage temperature for CD4 $+\mathrm{T}$ cell count specimen was at room temperature $\left(20^{\circ} \mathrm{C}\right.$ $-25^{\circ} \mathrm{C}$ ) and tested within $24 \mathrm{~h}$. For viral load testing, plasma was separated within $5 \mathrm{~h}$ and two aliquots of cryo-vials (with capacity of $1 \mathrm{ml}$ each) prepared for transportation. Specimen transportation was on dry ice and stored at $-80^{\circ} \mathrm{C}$ until the test is done. Centrifugation, pipetting and aliquoting were performed following standard protocol and laboratory bio-safety precautions both at collection and testing site. 


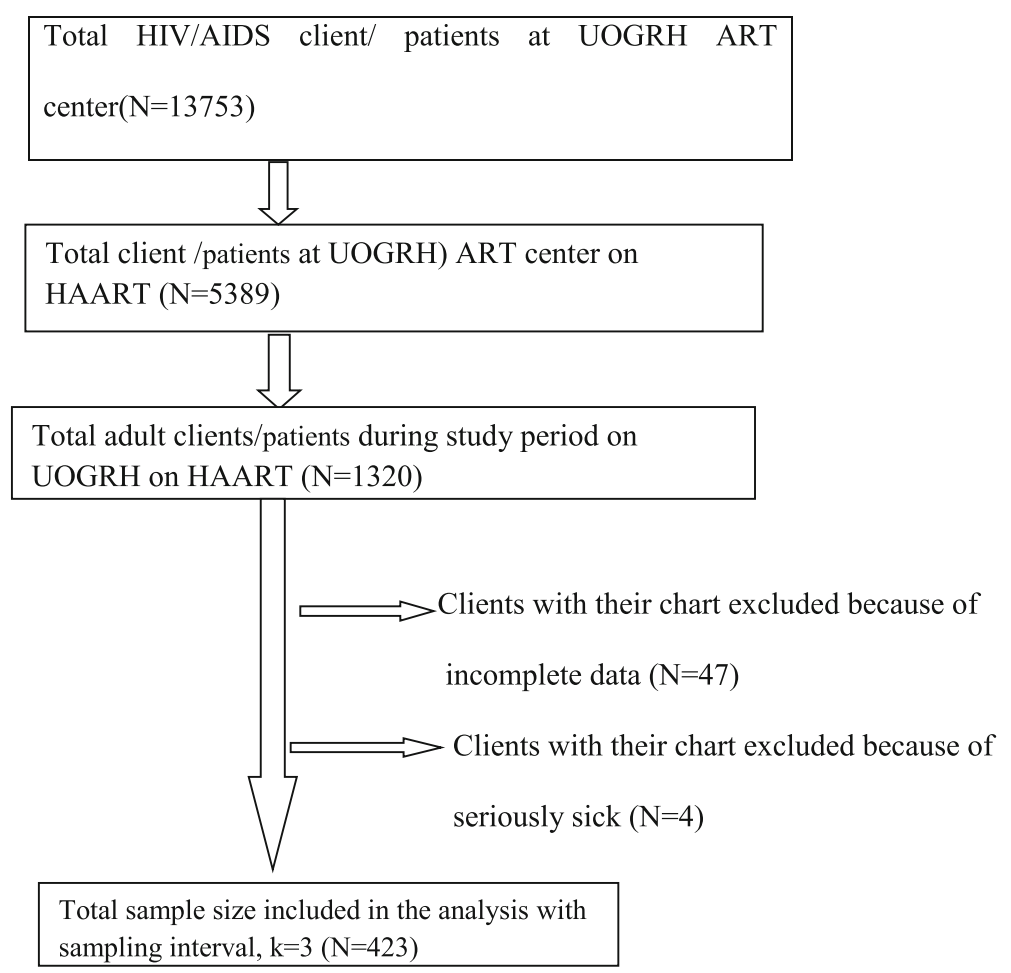

Fig. 1 Schematic representation of the sampling procedure of HIV positive adults on HAART at University of Gondar Referral Hospitals from February to April 2017

\section{Laboratory testing methods}

Following SOP quantification of absolute counts of CD4 $+\mathrm{T}$ cell on whole blood specimen was done using the FACS Calibur flow cytometer (BD, CA, America) in the laboratory. $\mathrm{CD} 4+\mathrm{T}$ cells count was done by adding $50 \mu \mathrm{l}$ whole blood to a reagent tube containing $20 \mu \mathrm{l}$ of monoclonal antibodies followed by vortexing and incubation for 30 min under dark condition.

Plasma viral load was measured using Quantitative Real-Time PCR HIV-1 assay by the COBAS $^{\oplus}$ AmpliPrep instrument (Roch, Homburg, Germany). Plasma was prepared from $5 \mathrm{ml}$ of blood by centrifuge at $3000 \mathrm{rpm}$ for $20 \mathrm{~min}$.

\section{Data processing and analysis}

Data were checked every day for its completeness, edited, cleaned and analyzed using SPSS version 21. Analysis was performed using univariate and multivariate logistic regression to determine the extent of the risk factors associated with ART treatment failure. The independent explanatory variable (s) of the dependent variable was selected at univariate analysis and included in multivariate analysis with $p$-value $<0.2$. The final association was prepared using multivariate logistic regression. $P$-value $<0.05$ was considered significant. After organizing the result in the form of frequencies and percentages, the data were summarized and described using text and tables.

\section{Ethical consideration}

Ethical clearance was obtained from the University of Gondar, School of Biomedical and Laboratory Sciences Ethical Review Committee and official letter was submitted to the University of Gondar Referral Hospital administration prior to data collection. Written informed consent was obtained from each study participants after explaining the purpose and objective of the study. Patients who were not willing to participate in the study were not forced to participate. All the data and samples obtained from them were kept confidential by using codes instead of any personal identifiers and meant only for the purpose of the study. The laboratory results from the study participants were communicated to their physicians for appropriate management.

\section{Results}

\section{Socio-demographic characteristics of patients}

A total of $423 \mathrm{HIV} / \mathrm{AIDS}$ patients who received ART were enrolled in the study. Of these, 272 (64.3\%) of them were female and 151 (35.7\%) were male. The mean (SD) age of the patients at study time was $39(+9.8)$ years (range 18-78 years). One hundred sixty-nine (40\%) of the patients were within the age group of 30-39 years. The mean weight of patients at the base line and at the time of the study (current) was $50 \mathrm{~kg}$ and $56 \mathrm{~kg}$, respectively. At the time of study almost half of patients, 209 
(49.4\%) were married and $343(81.1 \%)$ were living in urban areas. Three hundred eighty-six (91.6\%) were orthodox religion (Table 1).

\section{Clinical characteristics of HIV/AIDS patients}

The study patients were on ART with a minimum of 6 months up to 12 years with an average time of $7( \pm 3)$ years. Before ART initiation majority of patients had WHO clinical stage III and IV 269 (63.6\%), CD4 + T cell count $<200$ cells $/ \mathrm{mm}^{3} 267$ (63.1\%), good adherence 408 (96.5\%) and on AZT +3TC + NVP 156 (36.9\%) regimen followed by TDF + 3TC + EFV 87 (20.6\%).

While at the time of data collection $420(99.1 \%)$ had WHO clinical stage I and II, 44 (10.4\%) had CD $4+\mathrm{T}$ count $<200$ cells $/ \mathrm{mm}^{3}, 420$ (99.3\%) had good adherence and $162(38.2 \%)$ switched to either first line 150 (35.5\%) or second line regimen $12(2.8 \%)$. The most common reason for switching was toxicity 109 (67.3\%) followed by TB 18 (11.1\%). The common opportunistic infections observed during their ART follow up was TB 89 (21\%) (Table 1).

\section{Treatment failure and associated factors Overall failure}

Out of 423 ART patients, 86 (20.3\%) had either immunological or virological failure, $56(13.2 \%)$ had an immunological failure, 62 (14.7\%) virological failure and 20 (7.6\%) had both immunological and virological failure and $54(12.8 \%)$ was discordance.

\section{Immunological failure and associated factors}

Participants were followed for different periods and the total person-time of follow up was 3026 patient-years of follow up. Hence, the rate of immunological failure was $1.85 \%$ patient years of follow up. The mean plasma viral load level was 6906 copies/ml (range 0-298,869 copies $/ \mathrm{ml}$ ). Among all the study participants, 56 (13.2\%) of patients CD4+ $\mathrm{T}$ cell counts during follow-up were below baseline CD4+ T cell count or CD4 levels persisting below 100 cells $/ \mathrm{mm} 3$, or $50 \%$ fall from on-treatment peak value which indicates immunological treatment failure.

In bivariate logistic regression analysis associated factors such as: age of respondent, educational status, duration on ART, initial regimen and viral load during data collection were found to be a $p$ value of $<0.2$. When it was analyzed with multivariate logistic regression analysis duration of follow up on ART $\leq 6$ years, and VL $\geq 20$ copies $/ \mathrm{mm}^{3}$ were significant factors $(p<0.0001)$ for immunologic failure. Patients with a duration follow up on ART $\leq 6$ years $(\mathrm{AOR}=2.07(1.11-3.87), P=0.023)$ and $\mathrm{VL} \geq 20(\mathrm{AOR}=5.2(2.80-9.62), P<0.0001)$ were 2 and 5 times more likely to have immunological failure compared with their comparison $>6$ years and $<20$ copies/ $\mathrm{mm}^{3}$ respectively (Table 2 ).

\section{Virological failure and associated factors}

Participants were followed for different period and the total person-time of follow up was 3026 patient-years of follow up. Hence, the rate of virological failure was $2 \%$ patient years of follow up. The mean plasma viral load level was 6905.934 copies/ml (range 0-298,869.00 copies/ml). Among all the study participants, 62 (14.7\%) of patients were found to have viral load count of $>1000$ copies/ml which indicates virological treatment failure.

From bivariate analysis age, marital status, educational status, the reasonfor switching and CD4 count during data collection were had a $p$-value of $<0.2$. But multivariate regression analysis showed only $\mathrm{CD} 4+\mathrm{T}$ cell count during data collection $<200$ cells $/ \mathrm{mm} 3$ and default and age were significant factors $(p \leq 0.05)$ for virological failure. The CD4+ T cell count $<200$ cells $/ \mathrm{mm} 3$ (AOR $=10.09(2.47-41.29), \quad p=0.001)$ and default and age $(\mathrm{AOR}=7.20(1.99-25.94), p=0.003)$ was 10 and 7 times more likely to have virological failure compared with comparative group $\geq 500$ cells $/ \mathrm{mm}^{3}$ and toxicity respectively (Table 3 ).

\section{Discordance}

In bivariate analysis age of respondent, duration of ART and reason for switching of the drug had a $p$ - value of $<0.2$. However, reason for switching of drug (toxicity) were the only significant factors $(p \leq 0.05)$ for discordant with multivariate regression analysis. Switching of drug as a result of toxicity $(\mathrm{AOR}=11(2.16-56.09) p=0.004)$ was 11 times more likely to cause immune-virological discordance failure than switching of drug as a result of $\mathrm{TB}$, pregnancy default, and age (Table 4).

\section{Associated factors for treatment failure}

In a bivariate analysis, patients in the age between 18 and 29 years at the time of data collection were almost 3 times more likely to develop treatment failure (COR: 2.93; 95\% CI, $1.22-7.03 ; p=0.016$ ) as compared to age greater than 50 years. As the educational level increased the treatment failure decreased: patients who have no formal education (COR: 3.64; 95\% CI, 0.89-2.33; $p=0.043$ ), primary level education (COR: 3.81 ; 95\% CI, 1.09-13.31; $P=0.036$ ) and secondary level education (COR: 3.72; 95\% CI, 1.07-12.85; $P=0.038$ ) were 3.6 times, 3.8 times and 3.7 times, respectively as compared to those who have tertiary level education. However, patient had initial HAART regimen of D4T + 3TC + NVP (COR: 0.075: 95\% CI, 0.01-0.71; $P=0.0240), \quad \mathrm{D} 4 \mathrm{~T}+3 \mathrm{TC}+\mathrm{EFV} \quad$ (COR:0.02; 95\% CI, $0.001-0.25 ; P=0.003), \mathrm{AZT}+3 \mathrm{TC}+\mathrm{NVP}$ (COR: 0.06; 95\% CI, 0.01-0.57; $p=0.014), \mathrm{AZT}+3 \mathrm{TC}+\mathrm{EFV}(\mathrm{COR}$ : 0.04; 95\% CI, 0.003-0.44; $p=0.009)$, TDF + 3TC + EFV (COR: 0.05 ; 95\% CI, 0.01-0.46; $p=0.009$ ) were significantly protected from treatment failure as compared to patients who are on AZT $+3 \mathrm{TC}+\mathrm{NVP}$ of child 
Table 1 Socio-demographic and Clinical characteristics of HIV/AIDs patients in the University of Gondar referral hospital, 2017

\begin{tabular}{|c|c|c|c|}
\hline Variables & & Frequency & Percent \\
\hline \multirow[t]{4}{*}{ Age } & $18-29$ & 54 & 12.8 \\
\hline & $30-39$ & 169 & 40.0 \\
\hline & $40-49$ & 136 & 32.2 \\
\hline & $>=50$ & 64 & 15.1 \\
\hline \multirow[t]{4}{*}{ Marital status } & Single & 97 & 22.9 \\
\hline & Married & 209 & 49.4 \\
\hline & Divorced & 81 & 19.1 \\
\hline & Widowed & 36 & 8.5 \\
\hline \multirow[t]{2}{*}{ Gender } & Female & 272 & 64.3 \\
\hline & Male & 151 & 35.7 \\
\hline \multirow[t]{2}{*}{ Resident } & Urban & 343 & 81.1 \\
\hline & Rural & 80 & 18.9 \\
\hline \multirow[t]{8}{*}{ Occupation } & Farmer & 51 & 12.1 \\
\hline & Merchant & 58 & 13.7 \\
\hline & Student & 17 & 4 \\
\hline & government employ & 43 & 10.2 \\
\hline & daily laborer & 62 & 14.7 \\
\hline & house life & 101 & 23.9 \\
\hline & Private employ & 66 & 15.6 \\
\hline & Other & 25 & 5.9 \\
\hline \multirow[t]{4}{*}{ Educational status } & Illiterate & 121 & 28.6 \\
\hline & primary school & 117 & 27.7 \\
\hline & secondary school & 142 & 33.6 \\
\hline & Tertiary & 43 & 10.2 \\
\hline \multirow[t]{4}{*}{ Religion } & Orthodox & 386 & 91.3 \\
\hline & Muslim & 30 & 7.1 \\
\hline & Protestant & 7 & 1.7 \\
\hline & Total & 423 & 100.0 \\
\hline \multirow[t]{2}{*}{ Duration of ART in year } & $<=6$ & 162 & 38.3 \\
\hline & $>6$ & 261 & 61.7 \\
\hline Mean ART duration in year & 7 year $(+3)$ & 423 & $100 \%$ \\
\hline \multirow[t]{4}{*}{ Base line WHO stage } & WHO stage I & 57 & $(13.5)$ \\
\hline & WHO stage II & 97 & $(22.9)$ \\
\hline & WHO stage III & 214 & $(50.6)$ \\
\hline & WHO stage IV & 55 & $(13.0)$ \\
\hline \multirow[t]{3}{*}{ WHO stage during data collection } & WHO stage I & 11 & (2.6) \\
\hline & WHO stage II & 408 & $(96.5)$ \\
\hline & WHO stage III & 4 & $(.9)$ \\
\hline \multirow[t]{7}{*}{ Type of Opportunistic infection } & No & 308 & $(72.8)$ \\
\hline & Protozoa & 4 & $(.9)$ \\
\hline & Helminths & 12 & $(2.8)$ \\
\hline & Hepatitis viruses & 3 & $(.7)$ \\
\hline & fungal infections & 1 & $(.2)$ \\
\hline & $\mathrm{TB}$ & 89 & $(21.0)$ \\
\hline & Mixed & 6 & $(1.4)$ \\
\hline
\end{tabular}


Table 1 Socio-demographic and Clinical characteristics of HIV/AIDs patients in the University of Gondar referral hospital, 2017 (Continued)

\begin{tabular}{|c|c|c|c|}
\hline Variables & & Frequency & Percent \\
\hline \multirow[t]{8}{*}{ Initial regimen } & $\mathrm{D} 4 \mathrm{~T}+3 \mathrm{TC}+\mathrm{NVP}$ & 78 & $(18.4)$ \\
\hline & $\mathrm{D} 4 \mathrm{~T}+3 \mathrm{TC}+\mathrm{EFV}$ & 29 & $(6.9)$ \\
\hline & $A Z T+3 T C+N V P$ & 156 & (36.9) \\
\hline & $\mathrm{AZT}+3 \mathrm{TC}+\mathrm{EFV}$ & 30 & $(7.1)$ \\
\hline & $\mathrm{TDF}+3 \mathrm{TC}+\mathrm{EFV}$ & 87 & (20.6) \\
\hline & $T D F+3 T C+N V P$ & 31 & $(7.3)$ \\
\hline & $\mathrm{D} 4 \mathrm{~T}+3 \mathrm{TC}+\mathrm{NVP}$ & 6 & $(1.4)$ \\
\hline & Pediatric 4C (AZT + 3TC + NVP) & 6 & (1.4) \\
\hline \multirow[t]{3}{*}{ Switching } & No & 261 & $(61.7)$ \\
\hline & Yes & 162 & (38.3) \\
\hline & Total & 423 & $(100.0)$ \\
\hline \multirow[t]{2}{*}{ Switching } & To 1st line drug & 150 & (35.5) \\
\hline & To 2nd line drug & 12 & $(2.8)$ \\
\hline \multirow[t]{6}{*}{ Second regimen } & $A Z T+3 T C+N V P$ & 61 & 37.7 \\
\hline & $\mathrm{AZT}+3 \mathrm{TC}+\mathrm{EFV}$ & 25 & 15.4 \\
\hline & $\mathrm{TDF}+3 \mathrm{TC}+\mathrm{NVP}$ & 25 & 15.4 \\
\hline & $\mathrm{TDF}+3 \mathrm{TC}+\mathrm{EFV}$ & 39 & 24.1 \\
\hline & $A B C+d d l+L P V / R$ & 11 & 6.8 \\
\hline & $\mathrm{TDF}+\mathrm{ddl}+\mathrm{IPV} / \mathrm{R}$ & 1 & .6 \\
\hline \multirow[t]{5}{*}{ Reason of switching drug } & Toxicity & 109 & $(67.3)$ \\
\hline & Pregnancy & 7 & $(4.3)$ \\
\hline & TB & 18 & $(11.1)$ \\
\hline & Clinical failure & 1 & (.6) \\
\hline & Age & 9 & (5.6) \\
\hline \multirow[t]{3}{*}{ ARV drug $\mathrm{ADH}$ at base line } & Good & 408 & $(96.5)$ \\
\hline & Fair & 2 & $(.5)$ \\
\hline & Poor & 13 & (3.1) \\
\hline \multirow[t]{2}{*}{ ARV drug ADH During data collection } & Good & 420 & (99.3) \\
\hline & Poor & 3 & $(.7)$ \\
\hline \multirow[t]{4}{*}{ Base line CD4 count } & $<=199$ & 267 & $(63.1)$ \\
\hline & $200-349$ & 120 & (28.4) \\
\hline & $350-499$ & 27 & (6.4) \\
\hline & $>=500$ & 9 & $(2.1)$ \\
\hline \multirow[t]{4}{*}{ CD4 count during data collection } & $<=199$ & 44 & $(10.4)$ \\
\hline & $200-349$ & 110 & $(26.0)$ \\
\hline & $350-499$ & 114 & $(27.0)$ \\
\hline & $>=500$ & 155 & 36.6 \\
\hline \multirow[t]{5}{*}{ Viral load count } & Undetected & 224 & 53.0 \\
\hline & $0-19$ & 84 & 19.9 \\
\hline & 20-999 & 53 & 12.5 \\
\hline & $>=1000$ & 62 & 14.7 \\
\hline & Total & 423 & 100 \\
\hline
\end{tabular}


Table 1 Socio-demographic and Clinical characteristics of HIV/AIDs patients in the University of Gondar referral hospital, 2017 (Continued)

\begin{tabular}{llll}
\hline Variables & & Frequency & Percent \\
\hline Component of immunological failure & CD4 Falling More Than 50\% & 30 & 21 \\
& CD4 Falling Below Baseline & 53.6 & 37.5 \\
& CD4 Persistently Below 100 & 5.9 & 56
\end{tabular}

ADH adherence, ARV Antiretroviral, D4T Stavudine,TDF TenofovirDisoproxilFumarate, AZT/ 3TC Zidovudine/Lamivudine, EFV Efavirenze, NVP Nevirapine, $A B C$ abacavir, ddl didanosine, $L P V / R$ lopinavir/ritonavir, Mixed patients infected with more than two organism

regimen. In a multivariate logistic regression analysis, only patients who had no formal education (AOR: 3.8; 95\% CI, 1.05-13.77; $p=0.042$ ), primary level education (AOR: 4.2; 95\% CI, 1.16-15.01; $p=0.029$ ) and duration on ART < 6 years (AOR: 2.1; 95\% CI, 1.12-3.81; $p=0.021$ ) were a significant risk factor. (However, initial adult regimen D4T + 3TC+ EFV (AOR: 0.025; 95\% CI, 0.002-0.36; $p=0.007$ ), AZT +3TC + NVP (AOR: 0.07; 95\% CI, 0.01$0.71 ; p=0.025), \mathrm{AZT}+3 \mathrm{TC}+\mathrm{EFV}(\mathrm{AOR}: 0.046 ; 95 \% \mathrm{CI}$, 0.004-0.57; $p=0.016)$ and TDF + 3TC + EFV (AOR: 0.04; $95 \% \mathrm{CI}, 0.004-0.46 ; p=0.009)$ were significantly protective for treatment failure (Table 5).

\section{Discussion}

Identifying and managing treatment failure are a basic challenge for national treatment program. Sustainable treatment failure is related to difficulty to delivering quality care, the emergence of drug resistant viruses which limits the treatment option and increases the threat of morbidity and mortality. Thus the study was intended to assess the prevalence and associated factors of treatment failure among HIV/AIDS patients on HAART.

The prevalence of treatment failure as a result of immunological failure $56(13.2 \%)$ identified in this study

Table 2 Bivariate and multivariate analysis of risk factors for immunological failure on ART/AIDs patients attending University of Gondar Referral Hospital 2017

\begin{tabular}{|c|c|c|c|c|c|c|}
\hline \multirow[t]{2}{*}{ Variables } & & \multicolumn{2}{|c|}{ Immunological failure } & \multirow[t]{2}{*}{ COR(95\%Cl) } & \multirow[t]{2}{*}{$\mathrm{AOR}(95 \% \mathrm{Cl})$} & \multirow[t]{2}{*}{$P$ value } \\
\hline & & Yes & No & & & \\
\hline \multirow[t]{4}{*}{$\overline{\text { Age }}$} & $18-29$ & $13(24.1 \%)$ & 41 (75.9\%) & $2.58(0.95-7.04)$ & $0.96(0.25-3.66)$ & 0.955 \\
\hline & $30-39$ & $18(10.7 \%)$ & $151(89.3 \%)$ & $0.97(0.39-2.45)$ & $0.74(.26-2.09)$ & 0.570 \\
\hline & $40-49$ & $18(13.2 \%)$ & $118(89.3 \%)$ & $1.23(0.49-3.14)$ & $1.19(0.43-3.34)$ & 0.731 \\
\hline & $>=50$ & 7 (10.9\%) & $57(89.1 \%)$ & & & Ref \\
\hline \multirow[t]{4}{*}{ Educational status } & Illiterate & $18(14.9 \%)$ & $103(85.1 \%)$ & $2.33(0.65-8.34)$ & $2.05(0.53-7.92)$ & 0.297 \\
\hline & primary school & $17(14.5 \%)$ & $100(85.5 \%)$ & $2.27(0.63-8.16)$ & $2.14(0.57-0.14)$ & 0.265 \\
\hline & secondary school & $18(12.7 \%)$ & $124(87.3 \%)$ & $1.94(0.54-6.91)$ & $1.55(0.41-5.94)$ & 0.522 \\
\hline & Tertiary & $3(7.0 \%)$ & 40 (93.0\%) & & & Ref \\
\hline \multirow[t]{2}{*}{ Duration on ART in year } & $<=6$ & $30(18.5 \%)$ & $132(81.5 \%)$ & $2.05(1.16-3.62)$ & $2.07(1.11-3.87)$ & $0.023^{*}$ \\
\hline & $>6$ & $26(10 \%)$ & $235(90) \%$ & & & Ref \\
\hline \multirow[t]{8}{*}{ Initial regimen } & $\mathrm{D} 4 \mathrm{~T}+3 \mathrm{TC}+\mathrm{EFV}$ & $1(3.4 \%)$ & $28(96.6 \%)$ & $0.22(0.03-1.77)$ & $0.29(0.04-2.49)$ & 0.262 \\
\hline & $\mathrm{AZT}+3 \mathrm{TC}+\mathrm{NVP}$ & $20(12.8 \%)$ & $136(87.2 \%)$ & $0.89(0.41-1.98)$ & $0.73(0.28-1.92)$ & 0.529 \\
\hline & $\mathrm{AZT}+3 \mathrm{TC}+\mathrm{EFV}$ & $2(6.7 \%)$ & $28(93.3 \%)$ & $0.44(0.09-2.09)$ & $0.46(0.09-2.49)$ & 0.370 \\
\hline & $\mathrm{TDF}+3 \mathrm{TC}+\mathrm{EFV}$ & $10(11.5 \%)$ & 77 (88.5\%) & $0.79(0.32-1.98)$ & $0.50(0.16-1.59)$ & 0.239 \\
\hline & $\mathrm{TDF}+3 \mathrm{TC}+\mathrm{NVP}$ & $6(19.4 \%)$ & $25(80.6 \%)$ & $1.46(0.49-4.37)$ & $0.99(0.29-3.45)$ & 0.996 \\
\hline & $\mathrm{D} 4 \mathrm{~T}+3 \mathrm{TC}+\mathrm{NVP}$ & $2(33.3 \%)$ & $4(66.7 \%)$ & $3.04(0.49-18.67)$ & $1.173(0.18-7.49)$ & 0.866 \\
\hline & $\mathrm{AZT}+3 \mathrm{TC}+\mathrm{NVP}(4 \mathrm{C})$ & $4(66.7 \%)$ & $2(33.3 \%)$ & $12.18(1.99-74.67)$ & $12.90(1.17-142.67)$ & 0.051 \\
\hline & $\mathrm{D} 4 \mathrm{~T}+3 \mathrm{TC}+\mathrm{NVP}(4 \mathrm{a})$ & $11(14.1 \%)$ & 67 (85.9\%) & & & Ref \\
\hline \multirow[t]{2}{*}{ Viral load } & $>=20$ & $33(28 \%)$ & $82(72 \%)$ & $4.987(2.775-8.963)$ & $5.19(2.81-9.62)$ & $0.0001^{*}$ \\
\hline & $<20$ & $23(7 \%)$ & $285(93 \%)$ & & & Ref \\
\hline
\end{tabular}

Note: ${ }^{*}$ Has significant association

Those variables with in $p$ value $<0.2$ under bivariate analysis were included with in multivariate analysis

COR crude odds ratio, AOR adjusted odds ratio, Ref reference, $C l$ confidence interval, $p$ significant value, D4T Stavudine, TDF TenofovirDisoproxilFumarate, AZT/ $3 T C$ Zidovudine/Lamivudine, EFV Efavirenze, NVP Nevirapine 
Table 3 Bivariate and multivariate analysis of associated risk factors of virological failure on ART/AIDs patients attending University of Gondar Referral Hospital 2017

\begin{tabular}{|c|c|c|c|c|c|c|}
\hline \multirow[t]{2}{*}{ Variables } & & \multicolumn{2}{|c|}{ Virological failure } & \multirow[t]{2}{*}{ COR $(95 \% \mathrm{Cl})$} & \multirow[t]{2}{*}{$\mathrm{AOR}(95 \% \mathrm{Cl})$} & \multirow[t]{2}{*}{$P$ value } \\
\hline & & Yes & No & & & \\
\hline \multirow[t]{4}{*}{ Age } & $18-29$ & $15(27.8 \%)$ & $39(72.2 \%)$ & $4.53(1.52-13.49)$ & $2.18(0.28-16.98)$ & 0.456 \\
\hline & $30-39$ & $22(13.0 \%)$ & 147 (87.0\%) & $1.76(.63-4.88)$ & $1.15(0.25-0.45)$ & 0.858 \\
\hline & $40-49$ & $20(14.7 \%)$ & $116(85.3 \%)$ & $2.03(0.72-5.69)$ & $0.91(0.19-4.44)$ & 0.907 \\
\hline & $>=50$ & $5(7.8 \%)$ & $59(92.2 \%)$ & & & Ref \\
\hline \multirow[t]{4}{*}{ Marital status } & Married & 19 (9.1\%) & 190 (90.9\%) & $0.32(.16-.62)$ & $0.61(0.15-2.44)$ & 0.347 \\
\hline & Divorced & 14 (17.3\%) & $67(82.7 \%)$ & $0.67(.32-1.41)$ & $2.52(0.61-10.45)$ & 0.243 \\
\hline & Widowed & $6(16.7 \%)$ & $30(83.3 \%)$ & $0.64(.23-1.73)$ & $1.59(0.27-9.55)$ & 0.665 \\
\hline & Single & $23(23.7 \%)$ & $74(76.3 \%)$ & & & Ref \\
\hline \multirow[t]{3}{*}{ Reason of switching } & $\mathrm{Tb}+$ pregnant & $6(15.4 \%)$ & $33(84.6 \%)$ & $1.45(.50-4.18)$ & $1.15(0.37-3.57)$ & 0.811 \\
\hline & Default + age & $8(53.3 \%)$ & $7(46.7 \%)$ & $9.14(2.81-29.71)$ & $7.20(1.99-25.94)$ & $0.003^{*}$ \\
\hline & Toxicity & $12(11.1 \%)$ & 96 (88.9\%) & & & Ref \\
\hline \multirow[t]{4}{*}{ Current CD4 count } & $<=199$ & $2659.1 \%$ & $18(40.9 \%)$ & $23.43(9.50-57.77)$ & $10.09(2.47-41.29)$ & $0.001^{*}$ \\
\hline & 200-349 & 19 (17.3\%) & $91(82.7 \%)$ & $3.38(1.46-7.80)$ & $2.94(0.86-10.07)$ & 0.085 \\
\hline & $350-499$ & $8(7.0 \%)$ & 106 (93.0\%) & $1.22(.45-3.27)$ & $0.83(0.18-3.80)$ & 0.807 \\
\hline & $>=500$ & $9(5.8 \%)$ & $146(85.3 \%)$ & & & Ref \\
\hline
\end{tabular}

Note: ${ }^{*}$ Has significant association

Those variables with in $p$ value $<0.2$ under bivariate analysis were included with in multivariate analysis

$C O R$ crude odds ratio, $A O R$ adjusted odds ratio, Ref reference, $\mathrm{Cl}$ confidence interval $p$ significant value

was similar to those reported by other studies done in Bahir Dar [27] and SNNP region, Ethiopia [22] and Uganda [19] showing an immunological failure of 15.9, 11.5 and $11 \%$ respectively. However; our result was slightly lower than the study done in Bahir Dar Ethiopia. The difference might be as a result of the fact that the clients (patients) of the study participated in Bahir Dar were only under the first line HAART regimens, but our study patients were either under first or second- line of HAART regimen. Since most failures occur soon after the switch is made from the first line to a second-line therapy, a shorter follow-up period is most likely to find a higher probability of failure when compared to a study with a longer follow-up period.

Our finding showed that the duration of follow up on ART $\leq 6$ years $(P=0.023)$ was significantly associated with immunological failure and it was 2 times more likely to cause immunological failure than the duration of follow up on ART $>6$ years. This finding was inconsistent with a study done in French [32]. The discrepancy might be due to lack of assessment of new strain ART drug resistance viruses and its prevalence rate. If the duration of follow up on ART increases (late after the introduction of HAART drug in 2005 in Ethiopia),

Table 4 Bivariate and multivariate analysis of immuno-virologic discordant on ART/AIDs patients attending University of Gondar Referral Hospital 2017

\begin{tabular}{|c|c|c|c|c|c|c|}
\hline \multirow[t]{2}{*}{ Variables } & & \multicolumn{2}{|c|}{ Immune-virological failure discordant } & \multirow[t]{2}{*}{ COR(95\%Cl) } & \multirow[t]{2}{*}{$\mathrm{AOR}(95 \% \mathrm{Cl})$} & \multirow[t]{2}{*}{$P$ value } \\
\hline & & Yes & No & & & \\
\hline \multirow[t]{4}{*}{ Age } & $18-29$ & $10(52.6 \%)$ & $9(47.4 \%)$ & $0.27(0.04-1.66)$ & $2.46(0.104-0.04)$ & 0.577 \\
\hline & $30-39$ & $22(71.0 \%)$ & $9(29.0 \%)$ & $0.61(0.10-3.45)$ & $8.29(0.38-179.94)$ & 0.178 \\
\hline & $40-49$ & $14(53.8 \%)$ & $12(46.2 \%)$ & $0.29(0.05-1.64)$ & $6.51(0.27-154.25)$ & 0.246 \\
\hline & $>=50$ & $8(80.0 \%)$ & $2(20.0 \%)$ & & & Ref \\
\hline \multirow[t]{2}{*}{ Duration of ART in yrs. } & $<=6$ & $20(51.3 \%)$ & $19(48.7 \%)$ & $2.48(1.01-6.09)$ & $5.68(0.569-56.71)$ & 0.139 \\
\hline & $>6$ & $34(72.3 \%)$ & $13(27.7 \%)$ & & & Ref \\
\hline \multirow[t]{2}{*}{ Reason of switching drug } & Toxicity & $15(83.3 \%)$ & $3(16.7 \%)$ & $11(2.15-56.09)$ & $11(2.15-56.09)$ & $0.004^{*}$ \\
\hline & Others & $5(31.2 \%)$ & 11 (68.8\%) & & & Ref \\
\hline
\end{tabular}

Note: ${ }^{*}$ Has significant association

Those variables with in $p$ value $<0.2$ under bivariate analysis were included with in multivariate analysis $C O R$ crude odds ratio, $A O R$ adjusted odds ratio, Ref reference, $\mathrm{Cl}$ confidence interval, $p$ significant value 
Table 5 Bivariate vs multivariate analysis of treatment failure on adult HIV/AIDS patients attending University of Gondar Referral Hospital 2017

\begin{tabular}{|c|c|c|c|c|c|c|}
\hline Variables & & \multicolumn{2}{|c|}{ Treatment failure } & COR $(95 \% \mathrm{Cl})$ & AOR $(95 \% \mathrm{Cl})$ & $P$ value \\
\hline \multirow[t]{4}{*}{$\overline{\text { Age }}$} & $18-29$ & $19(35 \%)$ & $35(65 \%)$ & $2.93(1.22-7.04)$ & $1.59(0.54-4.72)$ & 0.398 \\
\hline & $30-39$ & $31(18 \%)$ & $138(82 \%)$ & $1.21(0.56-2.64)$ & $1.13(0.49-2.61)$ & 0.772 \\
\hline & $40-49$ & $26(19 \%)$ & $110(81 \%)$ & $1.28(0.57-2.84)$ & $1.31(0.56-3.04)$ & 0.530 \\
\hline & $>=50$ & $10(16 \%)$ & $54(84 \%)$ & Ref & & Ref \\
\hline \multirow[t]{4}{*}{ Educational status } & No formal education & $26(22 \%)$ & $95(79 \%)$ & $3.65(1.05-12.75)$ & $3.89(1.10-13.77)$ & $.035^{*}$ \\
\hline & primary school & $26(22 \%)$ & $91(78 \%)$ & $3.81(1.09-13.32)$ & $3.730(1.06-13.18)$ & $.041^{*}$ \\
\hline & secondary school & $31(22 \%)$ & $111(78 \%)$ & $3.72(1.08-12.86)$ & 2.93(0.83-10.38) & .096 \\
\hline & Tertiary & $3(7 \%)$ & 40(93\%) & Ref & & \\
\hline \multirow[t]{2}{*}{ Duration of ART in yrs. } & $\leq 6$ & $39(24 \%)$ & $123(76 \%)$ & $1.44(0.89-2.33)$ & $2.1(1.12-3.81)$ & $0.021^{*}$ \\
\hline & 6 & $47(18 \%)$ & $214(82 \%)$ & & & Ref \\
\hline \multirow[t]{9}{*}{ Initial regimen } & $\mathrm{D} 4 \mathrm{~T}+3 \mathrm{TC}+\mathrm{NVP}$ & $18(23 \%)$ & $60(77 \%)$ & $0.08(0.01-0.71)$ & $0.10(0.01-1.06)$ & 0.056 \\
\hline & $\mathrm{D} 4 \mathrm{~T}+3 \mathrm{TC}+\mathrm{EFV}$ & $2(7 \%)$ & $27(93 \%)$ & $0.02(0.001-0.25)$ & $0.03(0.002-0.37)$ & $0.007^{*}$ \\
\hline & $A Z T+3 T C+N V P$ & $31(20 \%)$ & $125(80 \%)$ & $0.06(0.01-0.57)$ & $0.07(0.01-0.72)$ & $0.025^{*}$ \\
\hline & $A Z T+3 T C+E F V$ & $4(13 \%)$ & $26(87 \%)$ & $0.04(0.003-0.44)$ & $0.05(0.004-0.57)$ & $0.016^{*}$ \\
\hline & $\mathrm{TDF}+3 \mathrm{TC}+\mathrm{EFV}$ & $14(16 \%)$ & $73(84 \%)$ & $0.05(0.01-0.46)$ & $0.04(0.004-0.46)$ & $0.009^{*}$ \\
\hline & $\mathrm{TDF}+3 \mathrm{TC}+\mathrm{NVP}$ & $9(29 \%)$ & $22(71 \%)$ & $0.102(0.01-1.045)$ & $0.11(0.01-1.25)$ & 0.075 \\
\hline & $\mathrm{D} 4 \mathrm{~T}+3 \mathrm{TC}+\mathrm{NVP}(4 \mathrm{a})$ child regimen & $4(57 \%)$ & $3(43 \%)$ & $0.33(0.02-4.736)$ & $0.32(0.02-4.76)$ & 0.408 \\
\hline & $A Z T+3 T C+N V P(4 c)$ child regimen & $4(80 \%)$ & $1(20 \%)$ & & & Ref \\
\hline & $A Z T+3 T C+N V P$ & 18(30\%) & $43(71 \%)$ & Ref & & \\
\hline
\end{tabular}

Note: ${ }^{*}$ Has significant association

Those variables with in $\mathrm{p}$ value $<0.2$ under bivariate analysis were included with in multivariate analysis

COR crude odds ratio, $A O R$ adjusted odds ratio, Ref reference, $C l$ confidence interval, $p$ significant value, D4T Stavudine, TDF TenofovirDisoproxilFumarate, $A Z T / 3 T C$ Zidovudine/Lamivudine, EFV Efavirenze, NVP Nevirapined, di Didanosine

the emergence of some new HIV drug resistance (HIVDR) strain is predictable as a result of HIV's error-prone replication, mutation rate and viral recombination. If this new strain HIVDR virus infects others, treatment failure may be occurring and management may not be effective. So patients with short duration of follow up ( $\leq 6$ year) on HAART has had two times the chance of acquiring the new strain drug resistant virus either during the duration of treatment follow up or initially by transmission than those patients infected with HIV (less likely drug resistant virus) before or early the introduction of ART even though those have had long duration of follow up ( $\geq 6$ year) on ART to acquire this new strain drug resistant virus. So the high prevalence of drug resistant virus with immunological failure through reduction of $\mathrm{CD} 4+\mathrm{T}$ cell count is expected in patients those ages is $\leq 6$ years than those have had $\geq 6$ years of follow up on ART.

Viral load $\geq 20(P=0.001)$ was the other significant factor for immunological treatment failure. This finding was consistent with other studies done in South Africa [33] and Eurosids [34] those showed viral load had the greatest impact on the CD4+ T cell decline. For patients with high viral load (more viruses) may trap more CD4+ cells in lymphoid tissue, which results in a low CD4+ cell count in blood [27].

The prevalence of treatment failure due to virological failure in our research was $14.7 \%$ (64/423) among the study participants. This finding was in agreement with a research done in Zambia [35] (11.7\%), Tanzania 12.3\% [36], Malawi 9.2\% [37], Nigeria 13.7\% [38], South Africa $13.7 \%$ [39] and Uganda 11.3\% [40]. However; our finding was lower than the other research done in Cameron 23.2 [41] and coastal Kenya 24\% [42] and slightly higher than the study conducted Uganda 9.9\% [19], Bahir Dar $10.7 \%$ [27] and Gondar 4.1\% [26]. The observed variation may be as a aresult of difference in geographical area, the study design, the endpoint of virological failure and sample size.

Our finding showed that CD $4+\mathrm{T}$ cell count during data collection $<200$ cells $/ \mathrm{mm} 3$ (AOR $=10.09$ (2.4741.29), $p=0.001$ ) were 10 times more likely to have virological failure contrasted with comparative group $\geq 500$ cells $/ \mathrm{mm}^{3}$ it was in line with the research done in Peru [43] and Kenya [44]. Since the diminishing of HIV-1-specific CD4 T helper cell, as a result of decline in CD4 T cell counts, qualitative impairments of CD4 T cell function and functional impairment of CD4 $\mathrm{T}$ cell 
indirectly lead to a functional impairment of HIV-1specific CD8 T cells [45] or B cell responses to control viral replication [46]. So the amount of viruses in the body increased.

In this research reason of switching as a result of default and age (AOR $=7.20$ (1.99-25.94), $p=0.003$ ) was 7 times more likely to have virological failure contrasted with the comparative group toxicity. It is inconsistent with studies done in Uganda [47] and Nigeria [48] those showed TB, breastfeeding, and pregnancy was significant for virological non-suppressed. This difference might be due to $9 / 15(60 \%)$ of switching as a result of default and age in our study were within the age range of $18-29$, with 53.3 virological failures. Those aged $<30$ years at the time of starting ART were more likely to break off the regimen [49] results in a significant rise of viral load.

Antiretroviral therapy treatment failure with immune-virologic discordance in our research was 54 (13\%). This finding was concordant with other research done in India that showed 28 (13.6\%) discordant patients [50]. However, a research carried out in Nigeria [45] showed 33\% immune-virologic discordance was inconsistent with our finding. This disagreement is most likely due to the difference in sample size (206 study subject) and study design (cohort study) that applied in Nigeria.

Our findings showed that only switching of drugs as a result of toxicity (AOR $=11(2.15-56.09), p=0.004)$ was significant factors for discordant results it is in line with other studies done from the computerized database retrospectively $[51,52]$. The potential causes might be marrow-suppressive medications and infiltrative bone marrow processes as a result of toxicity of known marrow suppressive drugs used in HIV-infected patients comprise zidovudine (Retrovir) and zidovudine-containing fixed combination pills that effect poor CD4 cell count responses in the setting of persistent virologic suppression and Toxicity as a result of TDF that causes the occurrence of bone fractures or changes in fat distribution this may also affect CD4 lineage [53].

Our study showed that the educational level was significantly associated with treatment failure. This finding was inconsistent with the research done in Addis Ababa, Ethiopia [54] and Bahir Dar, Ethiopia [27]. The difference may be due to the study participant awareness for treatment failure, for instance, the study participant in Addis Ababa were all from Urban but our study subject was comprised $79 \%$ urban and $21 \%$ rural with $23 \%$ no formal educational level.

Even though the regimen containing AZT + NVP can induce high incidence of the bone marrow suppression with encouraging high rate of lukimia, the goals of ART are actually the qualitative and quantitative immunological reconstitution and the maximum possible reduction of the viral load in the longest possible time $[1,55]$.
In line with that, the results of this research showed that initial adult regimens such as $\mathrm{D} 4 \mathrm{~T}+3 \mathrm{TC}+\mathrm{EFV}$ $(P=0.007), \mathrm{AZT}+3 \mathrm{TC}+\mathrm{NVP}(P=0.025), \mathrm{AZT}+3 \mathrm{TC}$ $+\operatorname{EFV}(P=0.016), \quad \mathrm{TDF}+3 \mathrm{TC}+\mathrm{EFV}(p=0.009)$ were significantly protective for treatment failure as compared to regimen AZT $+3 \mathrm{TC}+\mathrm{NVP}$. This finding was in line with the study done in Ethiopia [56].

Duration of follow up on ART $\leq 6$ years $(p=0.021)$ was significantly associated with treatment failure and was 2 times more likely to cause treatment failure than the duration of follow up on ART $>6$ years this is in line with the study conducted in the Malaysian state of Selangor [57]. This finding was not in line with research done in Bahir Dar, Ethiopia [22] Kumasi, Ghana [58]. This is most probably due to the lake of initial viral load measurement and increment of the transmission of the drug-resistant viruses.

\section{Limitations}

Acquired drug resistance testing was not done, because the testing facility has not been so far available in the country. The patient's clinical data was taken from the records retrospectively. Excluding patients who were seriously sick, since unable to get data during interview and lack of sufficient blood. The virological failure rates were assessed based on a single point testing of viral load, so there may be missed classification of HIV treatment failure. The prevalence of treatment failure is not really a populated-based estimate and is not representative of the broader population of people who are on ART and at risk of treatment failure. Despite these limitations, this study provides important information which would be useful for the ART treatment programs in the country.

\section{Conclusion}

The prevalence of treatment failure, immunological failure and virological failure among ART patients attending UOG referral hospital were 20.3, 13.2, and 14.7\% respectively. Fifty-four (13\%) patients were discordant. Even though no formal education, primary level education and duration on ART $<6$ years were a significant risk factor of treatment failure, initial adult regimen $\mathrm{D} 4 \mathrm{~T}+3 \mathrm{TC}+\mathrm{EFV}$, $\mathrm{AZT}+3 \mathrm{TC}+\mathrm{NVP}, \mathrm{AZT}+3 \mathrm{TC}+\mathrm{EFV}$, and TDF + 3TC + EFV were significantly protective. One of the following ART regimens: $\mathrm{AZT}+3 \mathrm{TC}+\mathrm{NVP}, \mathrm{AZT}+3 \mathrm{TC}+\mathrm{EFV}$ and $\mathrm{TDF}+3 \mathrm{TC}+$ EFVare recommended. Switching as a result of toxicity was significant risk factor of immuno-virological discordance. Since it is single ART center study, the result may not also be generalized to all hospitals, so further study is needed to be done in a wider community and multiple ART centers to determine whether there are differences in virological and immunological responses and immune-virological discordance to antiretroviral therapy at different stages of HIV infection. 


\section{Acknowledgments}

We would like to thanks the Department of Medical Microbiology School of Biomedical and Laboratory Science, Collage of Medicine and Health Science and University of Gondar for giving me this chance to conduct this research thesis.

\section{Funding}

Not applicable.

\section{Availability of data and materials}

All the data (SPSS) sets generated and/or analyzed in this study are available from the corresponding author on reasonable request.

\section{Authors' contributions}

GA: study design, data collection, analysis and interpretation, and manuscript write-up. GY: the conception of the research idea and supervision, BT, AA, GF: study design, data analysis and interpretation and supervision. All authors have read and approved the final manuscript.

\section{Ethics approval and consent to participate}

Ethical clearance from the University of Gondar, School of Biomedical and Laboratory Sciences Ethical Review Committee was received and an official letter to the University of Gondar Referral Hospital administration prior to data collection with Ref. No SBMLS/ 678/ 09 was submitted. Written informed consent was received from every study participants following the elucidation of the reason and the aim of the research. The study participants who were not agreeing to participate in the research were not forced to participate. All received data and samples from the study participants were kept confidential by using codes as an alternative of any personal identifiers for the purpose of the research. The laboratory results from the study participants were talking to their physicians for the suitable treatment purpose.

\section{Consent for publication}

Not applicable.

\section{Competing interests}

The authors declare that they have no competing interests.

\section{Publisher's Note}

Springer Nature remains neutral with regard to jurisdictional claims in published maps and institutional affiliations.

\section{Author details}

${ }^{1}$ College of Health Sciences, Mizan-Tepi University, P.O. BoX 206, Mizan Teferi, Ethiopia. ${ }^{2}$ Departhement of Medical Microbiology college of Medicine and Health Sciences, University of Gondar, Gondar, Ethiopia.

Received: 27 July 2018 Accepted: 30 November 2018 Published online: 17 December 2018

\section{References}

1. Department of Health and Human Services. Panel on Antiretroviral Guidelines for Adults and Adolescents. Guidelines for the Use of Antiretroviral Agents in Adults and Adolescents Living with HIV. Department of Health and Human Services, 2018. Available at http://www.aidsinfo.nih. gov/ContentFiles/AdultandAdolescentGL.pdf.

2. Ismail S, Mltike G, Hailemariam D. HIV/AIDS for the Ethiopian health center team. Ethiopia public health training initiative; 2002.

3. HG, Aachen PB et al. HIV Germany Medizin Fokus Verlag; Boston MA(USA)2012/2013. Available at: www.hivbook.com. Accessed 2 June 2018.

4. Ethiopia Country/Regional Operational Plan (COP/ROP) Strategic Direction Summary 2016; Available at: www.pepfar.gov/documents/organization/ 257650.pdf. Accessed 2 June 2018.

5. Madec Y, Leroy S, Rey-Cuille MA, Huber F, Calmy A. Persistent difficulties in switching to second-line ART in sub-saharan Africa: a systematic review and meta-analysis. PLoS One. 2013;8:e82724.

6. Melsew YA, Terefe MW, Tessema GA, Ayele TA. Rate of immunological failure and its predictors among patients on highly active antiretroviral therapy at Debremarkos hospital, Northwest Ethiopia: a retrospective follow up study. J AIDS Clin Res. 2013;4:211.

7. Aldous $\mathrm{JL}$, Haubrich RH. Defining treatment failure in resource-rich settings. Curr Opin HIV AIDS. 2009;4(6):459-66.
8. Liao L, Xing H, Su B, Wang Z, Ruan Y, Wang X, et al. Impact of HIV drug resistance on virologic and immunologic failure and mortality in a cohort of patients on antiretroviral therapy in China. AIDS. 2013;27:1815-24.

9. Cozzi-Lepri A, Phillips AN, Clotet B, Mocroft A, Ruiz L, et al. Detection of HIV drug resistance during antiretroviral treatment and clinical progression in a large European cohort study. AIDS. 2008;22:2187-98.

10. Deeks SG, Gange SJ, Kitahata MM, Saag MS, Justice AC, et al. Trends in multidrug treatment failure and subsequent mortality among antiretroviral therapy-experienced patients with HIV infection in North America. Clin Infect Dis. 2009;49:1582-90.

11. World Health Organization. [Webpage on the internet]. Antiretroviral therapy for HIV infection in adults and adolescents: recommendations for a public health approach [2010 revision]. Geneva: World Health Organization; 2010. Available from: http://whqlibdoc.who.int/publications/2010/ 9789241599764_eng.pdf. Accessed 10 Oct 2018

12. Intansari US, Dewi YP, Juffrie M, Soesatyo MH, Subronto YW, Mulyono B. Virological and immunological response to antiretroviral treatment in hivinfected patients. Indonesian J Clin Pathol Med Lab. 2017;23(1):67-73.

13. Gilson R, Man SL, Copas A, Rider A, Forsyth S, Hill T, et al. Discordant responses on starting highly active antiretroviral therapy: suboptimal CD4 increases despite early viral suppression in the UK collaborative HIV cohort (UK CHIC) study. HIV Med. 2010;11(2):152-60.

14. James $T$, Heiner $G$, John $C$, et al. Risk factors influencing HIV infection incidence in a rural African population a nested case-control study. Infect Dis. 2006;193:458-66.

15. Petersen ML, van der Laan MJ, Napravnik S, Eron JJ, Moore RD, Deeks SG. Long-term consequences of the delay between virologic failure of highly active antiretroviral therapy and regimen modification. AIDS. 2008;22(16): 2097-106.

16. Kantor R, Diero L, Delong A, et al. Misclassification of first-line antiretroviral treatment failure based on immunological monitoring of HIV infection in resource limited settings. Clin Infect Dis. 2009:49(3):454-62.

17. El-Khatib Z, Katzenstein D, Marrone G, et al. Adherence to drug-refill is a useful early warning indicator of virologic and immunologic failure among HIV patients on first-line ART in South Africa. PLoS One. 2011;6(3):e17518.

18. Johnston V, Fielding KL, Charalambous S, et al. Outcomes following virological failure and predictors of switching to second-line antiretroviral therapy in South African treatment programme. J Acquir Immune Defic Syndr. 2012;61(3).

19. Reynolds SJ, Nakigozi G, Newell K, Ndyanabo A, Galiwongo R, Boaz I, et al. Failure of immunologic criteria to appropriately identify antiretroviral treatment failure in Uganda. AIDS (London, England). 2009;23(6):697.

20. Ahoua $L$, Guenther $G$, Pinoges $L$, et al. Risk factors for virological failure and subtherapeutic antiretroviral drug concentrations in HIV-positive adults treated in rural northwestern Uganda. BMC Infect Dis. 2009;9:81.

21. Jaka HM, Mshana SE, Liwa AC, Peck R, Kalluvya S. Prevalence of immunological failure and durability of first line antiretroviral therapy at Bugando hospital Mwanza, Tanzania. Tanzan Med J. 2009;24:5-8.

22. Yirdaw KD, Hattingh S. Prevalence and predictors of immunological failure among HIV patients on HAART in southern Ethiopia. PLOS One. 2015;10(5):e0125826.

23. Davies MA, Moultrie $H$, Eley $B$, et al. Virologic failure and secondline antiretroviral therapy in children in South Africa: the international epidemiologic databases to evaluate AIDS (leDEA) southern Africa collaboration. J Acquir Immune Defic Syndr. 2011;56(3):270-8.

24. Ma $Y$, Zhao D, Yu L, et al. Predictors of virologic failure in HIV-1- infected adults receiving first-line antiretroviral therapy in eight provinces in China. Clin Infect Dis. 2010;50(2):264-71.

25. Datay MI, Boulle A, Mant D, Yudkin P. Associations with virologic treatment failure in adults on antiretroviral therapy in South Africa. J Acquir Immune Defic Syndr. 2010;54(5):489-95.

26. Ayalew MB, Kumilachew D, Belay A, Getu S, Teju D, Endale D, Tsegaye Y, Wale Z. First-line antiretroviral treatment failure and associated factors in HIV patients at the University of Gondar Teaching Hospital, Gondar, Northwest Ethiopia. HIV/AIDS (Auckland, NZ). 2016;8:141.

27. Bokretsion GB, Endalkachew N, Getachew KA. HIV/AIDS treatment failure and its determinant factors among first line HAART patients at FelegeHiwot referral hospital, Bahir Dar, Northwest Ethiopia. J AIDS Clin Res. 2017;8(11):4.

28. Joint United Nations Programme on HIV/AIDS (UNAIDS). 90-90-90 An ambitious treatment target to help end the AIDS epidemic. Geneva: 
UNAIDS 2014; Available at: http://www.unaids.org/en/resources/documents/ 2017/90-90-90

29. Agency CS. Population and housing census 2017 report, Amhara, part population size and characteristics. Adiss Ababa: Centeral Stastistic Agency; 2010. Available at: http://catalog.hsn.org/index.php/catalog/3583/download/ 50095.

30. National Guidelines on Second-line ART for adults and adolescents India: Department of AIDS Control National AIDS Control Organisation Ministry of Health \& Family Welfare Government of India May 2013; Available at: http:// naco.gov.in/sites/default/files/

National\%20Guidelines\%20on\%20Secondline\%20and\%20Alternative\%20Firstline\%20ART\%20For\%20Adults\%20and\%20Adolescents\%20May\%202013_0.pdf. Accessed June 42018.

31. Organization WH. March 2014 supplement to the 2013 consolidated guidelines on the use of antiretroviral drugs for treating and preventing HIV infection: recommendations for a public health approach. 2014. Available at http://www.who.int/hiv/pub/guidelines/arv2013/arvs2013upplement_ march2014/en/.

32. Raffi F, Le Moing V, Assuied A, Habak S, Spire B, Cazanave C, et al. Failure to achieve immunological recovery in HIV-infected patients with clinical and virological success after 10 years of combined ART: role of treatment course. J Antimicrob Chemother. 2016;72(1):240-5.

33. Martinson NA, Gupte N, Msandiwa R, Moulton LH, Barnes GL, Ram M, et al. Correction: CD4 and viral load dynamics in antiretroviral-Naiive HIV-infected adults from Soweto, South Africa: a prospective cohort. PLoS One. 2015; 10(6):e0130509.

34. Dragsted UB, Mocroft A, Vella S, Viard J-P, Hansen A-BE, Panos G, et al. Predictors of immunological failure after initial response to highly active antiretroviral therapy in HIV-1-infected adults: a EuroSIDA study. J Infect Dis. 2004;190(1):148-55.

35. ZAMPHIA. Zambia population-based HIV impact assessment, ZAMPHIA: 2015-2016. Summary sheet: preliminary findings. New York: PHIA Project; 2016. Available at https://phia.icap.columbia.edu/wp-content/uploads/2016/ 09/ZAMBIA-Factsheet.FIN_.pdf

36. Project PHIA. Tanzania HIV impact survey 2016-2017. New York: PHIA Project; 2017. Available at https://phia.icap.columbia.edu/wpcontent/ uploads/2017/11/Tanzania_SummarySheet_A4.English.v19.pdf

37. MPHIA. Malawi population-based HIV impact assessment, MPHIA: 20152016. Summary sheet: preliminary findings. New York: PHIA Project; 2016. Availabele at https://phia.icap.columbia.edu/wp-content/uploads/2016/09/ MALAWI-Factsheet.FIN_.pdf

38. Rawizza HE, Chaplin B, Meloni ST, Eisen G, Rao T, Sankalé J-L, et al. Immunologic criteria are poor predictors of virologic outcome: implications for HIV treatment monitoring in resource-limited settings. Clin Infect Dis. 2011:53(12):1283-90.

39. Mutevedzi PC, Lessells RJ, Rodger AJ, Newell M-L. Association of age with mortality and virological and immunological response to antiretroviral therapy in rural south African adults. PLoS One. 2011;6(7):e21795.

40. Kamya MR, Mayanja-Kizza H, Kambugu A, Bakeera-Kitaka S, Semitala F, Mwebaze-Songa $P$, et al. Predictors of long-term viral failure among ugandan children and adults treated with antiretroviral therapy. JAIDS J Acquir Immune Defic Syndr. 2007:46(2):187-93.

41. Meriki HD, Tufon KA, Afegenwi MH, Nyindem BA, Atanga PN, Anong DN, et al. Immuno-haematologic and virologic responses and predictors of virologic failure in HIV-1 infected adults on first-line antiretroviral therapy in Cameroon. Infect Dis Poverty. 2014;3(1):5.

42. Hassan AS, Nabwera HM, Mwaringa SM, Obonyo CA, Sanders EJ, de Wit TFR, et al. HIV-1 virologic failure and acquired drug resistance among first-line antiretroviral experienced adults at a rural HIV clinic in coastal Kenya: a cross-sectional study. AIDS Res Ther. 2014;11(1):9.

43. Jorge AR, Jorge PB, Elsa GL, Miguel CS, Rodriguez M, Willig J, et al. Risk factors associated with virologic failure in HIV-infected patients receiving antiretroviral therapy at a public hospital in Peru. Rev Chilena Infectol. 2013; 30(1):42.

44. Sang R, Miruka F. Factors associated with virologic failure amongst adults on antiretroviral therapy in Nyanza region, Kenya. IOSR J Dent Med Sci. 2016;15(7):10-21.

45. Lichterfeld M, Kaufmann DE, Xu GY, Mui SK, Addo MM, Johnston MN, et al. Loss of HIV-1-specific CD8+ T cell proliferation after acute HIV-1 infection and restoration by vaccine-induced HIV-1-specific CD4+ T cells. J Exp Med. 2004;200(6):701-12.
46. Lindqvist M, van Lunzen J, Soghoian DZ, Kuhl BD, Ranasinghe S, Kranias G, et al. Expansion of HIV-specific T follicular helper cells in chronic HIV infection. J Clin Invest. 2012;122(9):3271.

47. Bulage L, Ssewanyana I, Nankabirwa V, Nsubuga F, Kihembo C, Pande G et al. Factors associated with Virological non-suppression among HIVpositive patients on antiretroviral therapy in Uganda, august 2014-July 2015. BMC Infect Dis. 2017;17(1):326.

48. Anude CJ, Eze E, Onyegbutulem HC, Charurat M, Etiebet M-A, Ajayi S, et al. Immuno-virologic outcomes and immuno-virologic discordance among adults alive and on anti- retroviral therapy at 12 months in Nigeria. BMC Infect Dis. 2013;13(1):113.

49. Sabin C, Smith C, Delpech V, Anderson J, Bansi L, Gilson R, et al. The associations between age and the development of laboratory abnormalities and treatment discontinuation for reasons other than virological failure in the first year of highly active antiretroviral therapy. HIV Med. 2009;10(1):35-43.

50. Prabhakar B, Banu A, Pavithra H, Chandrashekhara P, Sasthri S. Immunological failure despite virological suppression in HIV seropositive individuals on antiretroviral therapy. Indian J Sex Transm Dis. 2011;32(2):94.

51. Negredo E, Moltó J, Burger D, Viciana P, Ribera E, Paredes R, et al. Unexpected CD4 cell count decline in patients receiving didanosine and tenofovir-based regimens despite undetectable viral load. AIDS. 2004;18(3):459-63.

52. Barreiro $P$, Soriano V. Suboptimal CD4 gains in HIV-infected patients receiving didano sine plus tenofovir. J Antimicrob Chemother. 2006;57(5):806-9.

53. Moore RD, Keruly JC. CD4+ cell count 6 years after commencement of highly active antiretroviral therapy in persons with sustained virologic suppression. Clin Infect Dis. 2007:44(3):441-6.

54. Niemeyer K, King A, Mengistu S, Hennig N. Predictors for antiretroviral therapy (ART) failure in an urban HIV/AIDS clinic in Addis Ababa, Ethiopia; 2016.

55. F. Z. Adverse effect of and treatment strategies during long term ART Clinical and Research center of infectious disease, Beiging DiTan Hospital, Capital Medical University, China 2015. Available at: http://regist2.virologyeducation.com/2017/hivAsia/07_Zhang.pdf. [cited 23 Dec 2018]

56. Haile D, Takele A, Gashaw K, Demelash H, Nigatu D. Predictors of treatment failure among adult antiretroviral treatment (ART) clients in bale zone hospitals, south eastern Ethiopia. PLoS One. 2016;11(10):e0164299.

57. Rahim MA, Hassan Y, Fahrni ML. Predictor factors for treatment failure among patients on second line antiretroviral therapy. Age. 2014;24(3):0.001.

58. Annison L, Dompreh A, Adu-Sarkodie Y. The immunological response of HIV- positive patients initiating HAART at the Komfo Anokye teaching hospital, Kumasi, Ghana. Ghana Med J. 2013;47(4):164-70.

\section{Ready to submit your research? Choose BMC and benefit from:}

- fast, convenient online submission

- thorough peer review by experienced researchers in your field

- rapid publication on acceptance

- support for research data, including large and complex data types

- gold Open Access which fosters wider collaboration and increased citations

- maximum visibility for your research: over $100 \mathrm{M}$ website views per year

At BMC, research is always in progress.

Learn more biomedcentral.com/submissions 